\title{
CIVIL-MILITARY COOPERATION IN PEACE OPERATIONS: THE CASE OF KOSOVO
}

Thomas R. Mockaitis

October 2004 